\title{
Beyond Neo-liberalism: Research Policies and Society. The Case of Japan
}

\author{
ALAIN-MARC RIEU
}

\section{Abstract}

The idea of decoupling is playing a major role in various interpretations of the present systemic crisis. This crisis is understood as an effect of neo-liberal policies, which have revolutionized economic systems since the 1980s. Decoupling indicates a qualitative change in the level of autonomy of the economic sphere in industrial societies. But a new level of differentiation also generates various types of recoupling, new forms of integration, cooperation and regulation recomposing social systems at another level. The goal of this article is first to situate the idea of decoupling within its conceptual complex. Secondly, the ecological constraint is considered the source of this intense differentiation within social systems, which has intensified since the 1970s. Finally, based on the case of Japan, this paper explains why large-scale science and technology policies developed since the 1990s have to be understood as part of a recoupling process, a project to reconstruct and reach a social and economic coherence in the long term. Similar policies are now implemented by all major industrial nations. Such policies have the potential to overcome neo-liberalism's negative effects.

Keywords: systemic crisis, ecological transition, neo-liberalism, science and technology policy, Japan

\section{Introduction: Social Systems under Stress}

Decoupling is a notion commonly used in the present systemic crisis to describe the intense differentiation process restructuring social and industrial systems as well as their interactions. But beyond the present crisis, this decoupling process finds its roots in the ecological transition reshaping industrial societies since the 1970s. Social systems have responded to this stress by searching for new recoupling processes. Two paradigmatic responses can be observed and compared: the neo-liberal paradigm, which has revolutionized the world since the 1980s, and a research and innovation paradigm taking shape in Japan since the 1990s. This paper concentrates on this second paradigm because it is replicated by many industrial nations and new industrial states. Studying the case 
of Japan illustrates the steps, problems and theoretical aspects of this paradigm. Comparing these two paradigms shows that the neo-liberal period is giving way to a new social and industrial model, still to be explored and fully conceptualized.

\section{Decoupling/Recoupling: A Model and Its Limitations}

Like all crises before, the present systemic crisis has reopened the search for new concepts and explanations. The idea of 'decoupling' has been playing a major role, explicit and tacit, in analysis of the present crisis and in the conception of various policies designed to respond to this situation. The idea is simple and powerful: 'decoupling' designates an increased differentiation of a function within a given 'system' (organism or organization), the resulting transformation of this function and the ensuing reorganization of this system by integration, cooperation or regulation. ${ }^{1}$ 'Decoupling' is therefore used to describe the reciprocal evolution of various systems (or subsystems in a system) within their environment. The idea of decoupling has a strong theoretical background: it belongs to the theory of complex adaptive systems reconstructed for research in human and social sciences. It carries therefore major presuppositions as well as a set of metaphors, models of explanation and scenarios for describing and explaining types of evolution, decoupling and recoupling processes. The main sequences of these processes are differentiation, specialization, autonomy and reconfiguration. The basic model is the following: when a decoupling is happening within a system, this emergent field of activity acquires a new degree of autonomy within this system; it builds its own rules, goals and interests. When this new field (or function) reaches a certain degree of autonomy, it tends to impose its rules, goals and interests on other components of this system. This situation generates disorder, tensions and even conflicts; it can disarticulate the system but it can also lead to its reorganization into a new system. The notion of 'decoupling' and its source model provide interesting descriptions but there is no proof they provide an effective knowledge of these processes.

From the beginning of the 2007-2011 financial, economic, social, monetary and political crisis, the idea of decoupling was used to describe and predict its short-term impact and long-term consequences. The main prediction was a further and even final decoupling between East Asian economies and the American economy, even all Western economies, as well as between China and the rest of the East Asian economies. ${ }^{2} \mathrm{~A}$ 'new emerging order' was predicted, with China taking the lead and 
eventually carrying the world economy out of recession. But when all constraints are taken into account, the validity of this prediction is not based on factual data but on the power of the theory behind the idea of decoupling. In fact, China's growth does not carry the world economy in proportion to its exports. The Chinese population saves too much due to underdeveloped social policies (education, health, pensions). It does spend enough to sustain the Chinese economy but not enough to sustain the world economy.

This example shows that the theory behind decoupling is neither false nor true. It opens and frames a range of discourses leading to description, explanation and prediction, which are not easily or directly falsified. It leads also to a powerful hypothesis taken for a standard explanation: ${ }^{3}$ the regression of the emerging world from the 1980s to the late 1990s is explained by accumulated debts and deficits, which have dried up investment capacities. These deficits and debts had to be absorbed in order to restore conditions of economic growth and social development. The nations that have achieved this restoration, along with China and Russia, are the new emerging economies. Wealth and power have been redistributed around the world. This transformation of the world economy partly explains the globalization process of the 1990s. But since the beginning of the 2007-2011 systemic crisis, ${ }^{4}$ the same explanation has been used for all industrial nations, including Japan. Various policies, which have been debated and implemented, reproduce the same set of presuppositions, turning an explanation into a prediction.

The standard discourse is the following: for mature industrial nations, including Japan, the main effect of globalization has been increased competition and reduced competitiveness, rising amount of private and public debts, of deficits and bad loans, which led to the present crisis. Therefore, in order to overcome their present crisis, Western economies need to absorb their debts, reduce their deficits and restore their competitiveness. According to this scenario, East Asian economies should lead or participate in the world recovery and generate global economic growth. Interestingly, in this discourse, Japan remains paradoxically outside and inside the present stage of the world system; it benefits from the growth of East Asian economies but it also carries all the burden of a mature economy: massive debts, loss of competitiveness, unemployment and the related crisis of its social system. Indeed, no government in Japan seems able to find a solution, to restore its financial and economic situation and to reduce its dependence on East Asian economic growth. 
Such scenarios have obviously inspired and explain various American and European discourses and even policies since 2008. But their predictive value is weak. They do not take into account disruptive events because such events are unpredictable from the point of view of the theory. First, they do not explain the cause of the new dynamics of differentiation, which has since the 1970s deeply transformed societies and social systems as well as the world order. This main cause was the energy crisis and the rising cost of all energy and raw materials. Second, these scenarios do not explain the new level of decoupling of the economic sphere, which has revolutionized economies and societies since the 1980s, nor the formation of neo-liberal doctrines and practices, which have explained, justified and managed this decoupling. Finally, they concealed the long-term characteristic of the period starting in the late 1970s and 1980s and lasting until today: the conception and implementation in all industrial nations of large-scale research and innovation policies, which nowadays are supposed to drive their long-term future. These three evolutions and processes are closely related to each other. Therefore the real heuristic value of the theory of decoupling and recoupling is to analyze social and economic systems and their evolution from the point of view of disruptions and as a response to disruptions. This is the goal of this article.

\section{The Great Disruption: The Ecological Challenge}

The disruptive event at the source of the evolution transforming societies and economies, the conditions of their development and the world order, can now be identified as the first crisis of energy and natural resources, which first erupted in 1973 and lasted until 1982. In 40 years, this energy crisis has developed into a global 'ecological challenge ${ }^{15}$ to all societies, transforming the course of their evolution and relations. The price of oil quadrupled in 1973. In 1981-1982, Iran's oil embargo was the main cause of the US 1982 recession. In retrospect, this crisis was much more than a problem of increased cost and free access. It touched the core of each industrial society, their infrastructure, which holds together the social, political and economic system. We now understand that since the end of the nineteenth century, and certainly after 1945, industrial economies could develop and grow only by controlling the cost of energy and raw materials. The worldwide control of cost, access and transport of natural resources was the condition for the development of each industrial nation. Companies could make profits because 
of steady and strong demand based on a high level of employment and consumption as well as various social programs financed by taxes on profits, consumption and income. The welfare state, consumer society and market-based social capitalism are variations of the same system. The adjustment variable was the cost of energy and open access to all natural resources. This cost expressed the need for capitalist societies to sustain trade and industry in order to create jobs, to stimulate demand and maintain social stability. Managing such a system required a comprehensive state, a skilled and broad administration.

This economic and social structure historically shaped its biophysical environment into its own ecology. ${ }^{6}$ The biophysical environment was reduced to raw materials and energy sources and so-called 'nature'. Some nations had the financial and industrial, technological and military capacity to control the technology as well as the production sites, the transport and distribution of oil and other natural resources around the world. After 1945, the US possessed the power to control all capitalist economies and societies of the so-called 'free world'. This also explains US foreign policy until today and the size and level of deployment of US military around the world. It finally explains the organization of power within the US itself, and the role of energy and defence industries during the G.W. Bush administration. Since 1945, US foreign and military policy has had as a goal to secure access to and transport of energy and natural resources around the world. ${ }^{7}$ Today the cost of this control has become unsustainable. The energy and raw materials crisis of the 1970s was the moment when the core system of the 'free world', of all industrial nations under American military, industrial and technological hegemony, was destabilized and started deconstructing. In retrospect, this was not a 'crisis' to be overcome but the beginning of a historical transition. This transition opened a series of decoupling and rifts within this world system, which have been controlled, managed and repressed since the 1980s until the mid-2000s by US economic and military hegemony. Today these fault lines are in the open and fully recognized. Policies responding to this situation are still difficult to conceive, to justify and implement, because they touch the infrastructure of each industrial society.

According to this perspective, what is at stake can be conceptualized in five points. First, the oil crisis of the 1970s has become, since the mid2000s, the ecological constraint, which is transforming the evolutionary trajectory of all industrial social and economic systems. The present economic crisis cannot be separated from the long-term ecological 
constraint. Secondly, this situation generates serious problems within each social and economic system: pollution and health hazards, climate change, global warming, water and fertile land shortages, competition for access to rare minerals, etc. The ecological constraint acts both from outside and within each system. These systems respond and adapt by differentiation and reconfiguration but this constraint reaches so deep into each system that their adaptive response is unpredictable. Thirdly, these disruptions within each social system have major geopolitical consequences. They intensify competition between industrial nations to secure the long-term conditions of national sovereignty, economic development and social stability. The fourth point concerns the present conjuncture: in this late 2011, the 2007-2011 crisis represses on the shortterm but reinforces on the long-term the ecological disruption. The interactions between these two crises are neither explicitly nor publicly debated. Governments and international institutions concentrate on the economic crisis: the risk is that short-term policies responding to the economic crisis might be counter-productive considering the long-term ecological transition.

In summary, the decoupling/recoupling model has been reinterpreted in order to take into account the ecological constraint. It now describes a type of adaptive evolution taking place at the level connecting a social and economic system to its biophysical environment. The problem now is to study types of evolution, which since the 1970s have been a response to the massive disruption situated at the core of all industrial societies. The main benefit of this approach is to put in perspective the neo-liberal revolution, which has transformed the world since the 1980s. In retrospect, this revolution was and still is a systemic response to the long-term ecological constraint. But the same perspective makes us also understand that neo-liberal ideology and policies have not been and are not the only response to this constraint.

\section{Two Systemic Responses. The Neo-liberal Paradigm}

Today one can clearly identify two systemic responses to the decoupling generated by the ecological disruption, two different types of recoupling. Neo-liberal policies conceived and implemented since the 1980s, first in the US and then in the rest of world, are the first response. But science and technology policies conceived and implemented in Japan since the 1980 s constitute a second and alternative response. A 'Chinese wall' has never separated these two sets of theories, policies and practices. They 
overlap and interact but they have different sources, histories and consequences: this explains why they need to be contrasted from each other. They require different institutional arrangements and generate different social and cultural evolutions. Most important, they are strongly competing with each other. ${ }^{8}$ Until now, nearly all policies designed to overcome the 2007-2011 crisis have been versions of the neo-liberal paradigm. But in the last ten years, the research and innovation paradigm has been reinvented or reproduced by many industrial nations, including South Korea, Singapore, China, and recently, India and Russia. For the moment, the divergence between the two paradigms is not seen as leading to contradiction. But science and technology policies designed in the US since the 1980s have very different sources, institutions and impact than the policies designed by Japan's techno-structure in the 1990s. The present systemic crisis increases the divergence between these two paradigms.

The response to the energy crisis differed from nation to nation. But each nation and government, each economy and each company had to face the same problem: the rising cost of energy and raw materials was increasing production costs, reducing national competitiveness and intensifying international competition. The second problem was to decide how those increased production costs could be translated into increased prices on the market. In all industrial nations, the economic crisis induced by rising energy costs was reinforcing competition and this competition had become destructive. In the late 1970s, companies were starting to close, unemployment was rising, and taxes were bringing less revenue. Social policies were starting to show important deficits. In order to remain competitive, companies and industries had to imagine how to reduce costs without reducing consumption and demand.

In the late 1970s and early 1980s, there were clearly three ways to sustain competitiveness and they have all been implemented to some degree. The first solution was to stall and even lower salaries, the second solution was to reduce employment. A third solution was to reduce the cost of government and state administration in order to lower taxes, either taxes on citizens in order to strengthen demand, savings and investment, or taxes on businesses and profits. This third solution included reducing social programs and benefits in education, health, security and pensions. But there was also a fourth solution: to invest massively in science and technology so that innovation would neutralize added energy costs and increase productivity by creating new industries, industrial processes and services, which would reduce dependency on natural 
resources and alleviate ecological constraints (pollution, global warming, shortages). This fourth solution is based on new models, theories and policies, mainly the theory of 'national system of innovation ${ }^{19}$ and a new discipline, the economics of innovation. Until today, industrial nations have not found any alternative solutions. They have only found equilibrium between these four possibilities according to their own history and culture. For instance, in the case of France, budget deficits started to increase in 1973 and 1974, unemployment rose to around 10 per cent of the active population in the early 1980s and stayed at this level until now, with rare momentary reductions.

This first response is well known and will receive only a short summary here because this article focuses on the research and innovation paradigm, specifically, on its Japanese version. The reason is this paradigm is replicated by a growing number of governments and the neoliberal paradigm might be receding in the near future. Neo-liberalism is a vision of society, of individuals in society, of institutions and historical evolution. As proven by its amazing resilience, it is not a theory easily falsified by events or facts. Neo-liberalism has been constantly reformulated to overcome all criticism. According to a complex adaptive systems perspective, neo-liberalism is the name given in the late 1970s to a new level of decoupling ${ }^{10}$ between the economy, society and the state (both the government and the administration). This decoupling was not the triumph of an ideology or political party but it was, as explained above, a response within social and economic systems to increased costs of energy and natural resources. When Ronald Reagan was elected president in 1980, the relation between the energy crisis and his program was not explicit: the US economy was simply in crisis, its hegemony was questioned and had to be restored. But government was considered too big, too costly and inefficient. Social programs were viewed not only as too costly but even counter-productive: in time of crisis, protecting people from economic change was preventing them from becoming full economic actors finding solutions to their own problems. Decoupling (the words used were 'freeing' and 'deregulation') the economy was until today the ideology of successive American administrations. From a systemic point of view, this increased level of autonomy of the economic sphere has been the response of our institutional systems to a long-term ecological mutation.

Neo-liberalism became, in the early 1980s, a model and a norm, which has revolutionized economies and societies around the world. The US identified itself with this norm as an expression of US economic and 
political power. Successive US administrations tried to persuade other nations to implement reforms to reorganize their economy, society and government according to this imagined American model and to emancipate their economic system from historical constraints in order to become similar or compatible with this American model. ${ }^{11}$ But the main target of these reforms was East Asia, and within East Asia, Japan. Even if major reforms were achieved, especially after the 2007 East Asian crisis, these nations tacitly resisted any real convergence with the US neo-liberal model (Lee 2008; for a different angle, see Dore 2004). The loudest advocate for liberal reforms in East Asia has been Junichiro Koizumi, Japan's prime minister from 2001 to 2006, but in retrospect, his achievement is considered ambiguous and even weak (Vogel 2006). ${ }^{12}$ Neo-liberal reforms were more a political platform to win elections than a program to be implemented. Today, the 2008-2011 crisis appears as a long-term consequence of the 'neo-liberal turn' of the late 1970s. But neo-liberal policies are still considered the paradigm to conceive, negotiate and implement proper answers to the crisis, plus an added level of legal regulation. ${ }^{13}$

In the early 1980s, a decisive evolution reshaped the US economy. As explained above, science and technology policy is one of the four potential responses to the ecological constraint and its decoupling effect. Until the 1980s, the framework in the US to design and implement science and technology policies remained within the trajectory opened after 1945 by the 'new frontier' ideology, which led to the creation of the National Science Foundation in 1950. Science, technology and their institutions remained under the control of the US political, defence and industrial system in order to participate in their strategy for reaching their goals. Within the new neo-liberal paradigm, their role, organization and management became a major issue: they had to share its models and be reformed according to its specific goals. In 1980, the Bayh-Dole Act reformed the post-World War II industrial property regime regulating the availability and circulation of 'inventions' produced in universities by public and private sector cooperation. This reform gave universities the right to sell to private companies licenses of innovations produced on campuses and financed by public funds. In ten years, this reform resulted in a quantum leap in science and technology. It transformed universities and their relations to industry and government. It led to the formation of new industries, mainly in information and communication technology (ICT) and biotechnology, which changed the world. It extended and reinforced American science and technology hegemony. 
But to sustain this 'advance' and level of progress in the long term proved to be a major challenge after the 2000 internet bubble burst. This 'new economy' proved fragile and new reforms were needed. Since the 1980s, universities, research institutes, innovation processes and education have undergone deep reforms according to the neo-liberal paradigm, sharing progressively its models of organization and management, but also its goals and values. These reforms had a similar effect on universities and education in general as they did on society and firms: some of them may have become more efficient, competitive or successful but most of them were disorganized, without a clear sense of their goals and responsibilities in society as a whole. The neo-liberal decoupling process generated successive reforms, but no clear and effective recoupling process can be observed. It does not seem to reach any end; it does not seem to touch a bottom for rebound.

\section{The Research and Innovation Paradigm: The Case of Japan}

Neo-liberalism is an ideology and an institutional arrangement characterized by an increased level of autonomy of the economic sphere, which emerged in the late 1970s and early 1980s as a response to the ecological challenge. But there was another answer to this growing ecological challenge. An alternative response was imagined and implemented in Japan. Still there is no Japanese model to be imitated and reproduced, but a Japanese experience to learn from. My goal now is to formulate this alternative paradigm. Developed first in Japan, it has been reproduced or rediscovered by all industrial nations since the late 1990s. This paradigm has become a model of development for the European Union and for many advanced new industrial nations, for South Korea, Taiwan, Singapore, and even China.

In the case of Japan, the research and innovation paradigm developed in four steps. The first step was a diagnosis and a response designed around 1972 by Japan's techno-structure, even before the beginning of the energy crisis in 1973. ${ }^{14}$ The energy crisis and the rising cost of all raw materials from 1973 to 1982 were undermining the fundamentals of Japan's economy, rebuilt with great difficulty and effort after 1945. Japan was importing nearly all its energy and raw materials. The shock was intense and it concerned not only energy supplies. The threat was considered as serious for Japan's sovereignty as the threat of colonization in the mid-nineteenth century. The response to the crisis was organized 
and managed by the celebrated MITI (Ministry of International Trade and Industry) in close cooperation with the major industrial and commercial firms, universities and 'national laboratories'. In early 1980s, this response was considered a success. In a few years, the Japanese economy had gone through an industrial and technological mutation; its dependency on imported energy and raw materials had been controlled by a major increase in productivity based on automation. Japan's coherent and successful response was studied in great detail. It became the model of a national public policy managing long-term economic development on the basis of a science and technology policy geared toward innovation. The Japanese experience led to the construction of a powerful concept and influential public policy model (Freeman 1987, 1988), the 'national system of innovation'. ${ }^{15}$

This reorientation and reorganization of Japan's economy has had longterm consequences, lasting until today. The initial strategy was a progressive conversion of all industries toward production of higher added value and new industrial processes. Computerization was intended first to compensate the rising cost of all natural resources but also to reorient industry toward activities and products where these costs were neutral or neutralized. In summary, the strategy was to substitute high addedvalue production for natural resources and labour. From the beginning, it included the project to retrain labour in order to orient workers toward high-value activities. This strategy was also based on the development of a strong microprocessor industry as well as large consumer electronics firms for worldwide markets (Fransman 1990). Such a coordinated strategy could only be conceived and achieved by an institutional environment organized around a powerful and dedicated administration (Johnson 1982). ${ }^{16}$ In the early 1980s, Japan's techno-structure had responded to the crisis by establishing an endogenous dynamic of great intensity and spectacular success. This 'virtuous cycle' is the core of Japan's economic growth in the early 1980s. It is also the core of Japan's economic resilience after the 1985 endaka, the abrupt rise of the yen decided by the Group of Five (G5) to curb and control Japanese competitiveness. A new paradigm had been invented in Japan: responding to the ecological constraint and to economic competition by organizing a high-value-added economy based on research and innovation (Sakaiya 1991; see also Kodama 1991, 1995). ${ }^{17}$ This paradigm implied quite a different institutional environment and policy matrix from neo-liberalism.

Japan's success in the early 1980s induced a strong wave of chauvinism: Japan was unique and the best. ${ }^{18}$ But administrative, academic and 
business elites did not share this euphoria, at least not in private. What had been achieved was also a source of worry. The Japanese economy was fully riding the 'third wave' (Toffler 1980), ${ }^{19}$ the last technological wave, information and communication technology. For Japan, a 'postindustrial society' was an 'information society' (Ito 1991). The infrastructure of such a society, the conditions of its development, was a generic technological innovation. But this technological wave was not born in Japan: it was imported from the US and exploited in Japan. Japan had been able to organize an institutional structure based on patterns of collaboration between laboratories in universities and firms and public agencies. This collaborative structure, a real 'ecosystem of innovation', had been capable of identifying the potential of a new technology, organizing research and development capacities to explore this technology in depth, and making and applying innovations to many different fields, leading to new industrial processes, new departments in existing firms (even new firms) and finally new products commercialized worldwide. If China is today the world factory, Japan was in the 1980s an innovation factory. Japan was in advance, not in the production of new knowledge, but in the transformation of this knowledge into new products.

For the Japanese techno-structure, this very success was creating dependency on those nations at the source of these technological mutations, namely the US. Technological dependency could be in the future as serious a threat as energy dependency in the 1970s, even of colonization in the mid-nineteenth century. A response took shape and led to new policy at the end of 1980s: Japan had to prepare for the new technological wave and to create the conditions to produce this next wave in order to establish its long-term endogenous economic and social development. The next wave did not have to be Japanese or to come from Japan. But Japan's research and teaching institutions had to participate from the beginning in the invention of this next wave, whatever it would be and at whatever cost. This is the second step in the formation of the research and innovation paradigm, which does not fully fit in the national system of innovation concept. Japan had to fully collaborate in advanced research in all domains. But in order to achieve this goal, reforms were necessary: universities and research institutes had to be reorganized and opened to worldwide collaboration. The dynamics of a new technology was so powerful and disruptive, its development costs and the complexity of its emergence were so great, that the cost of catching up had become too high and would soon become impossible to match. What was at stake was Japan's future as a fully sovereign nation. 
This diagnosis was not contradicted, but to the contrary, was confirmed by the 'bubble crisis', the financial, economic, social and political crisis, which erupted in 1991. Its effects have lasted up to today. ${ }^{20}$ The 1990s opened the age of large-scale science and technology programs (Rieu 1996). It was a difficult choice, difficult to organize, finance and manage. ${ }^{21}$ But it was also fully consistent with Japan's modern history and with the role of technology in its modernization. An economist, Matsumoto Kazuo, best expressed the situation: 'Technology is Japan's only resource. It is time now to develop it'. ${ }^{22}$ To summarize this new situation, until the 1980s, development was prevalent over research; the goal now was to reach a stage where research done in Japan's leading universities would feed Japan's industrial and social innovation. This evolution was called in Japan, the emergence of a 'post-information society' or more adequately, a 'knowledge society'.

In the early 1990s, the 'bubble' crisis forced the administration to restructure Japan's research system. The proliferation of programs in the 1980s was costly and inefficient and far below expectation. Because of the number of partners (ministries, companies, universities, etc.) involved and the fields concerned, two large programs were organized: the Industrial Science and Technology Frontier Program and the New Sunshine Program for new energy sources and environmental technologies. Their demarcation shows Japan's long-term priorities: the goal was explicitly to respond to the ecological constraint by articulating green research and industry in the hope of building a different social and economic system. This restructuring led to a final reform establishing a new and coherent research and innovation system of unprecedented scale (Rieu 2007). The goal for Japan was not simply to have a strong science and technology policy, but to become an open system of innovation, articulating the national interest and international cooperation. The objective was to build this policy within the institutional system and in return to adapt the institutional system to the role and output of this policy. In 1995, Basic Law for Science and Technology was passed. According to this law, three basic plans were developed from 1996 to 2011. Spending on science and technology increased from 12.6 trillion yen 1995 to 17.6 for the first plan, 21.1 trillion for the second and 21 trillion for the third plan. The size of these budgets tells little about the plans themselves, their construction, intentions and internal dynamics. The first two plans had as goals to reform Japan's system of research, innovation and education. The third basic plan opened a different dynamic: to transform the interactions between research and innovation activities within both society and the economy. 
The First Basic Plan, from fiscal 1996 to 2001, aimed to open a new phase by increasing the public budget for science and technology 60 per cent in five years. In spite of the crisis, the budget was granted. The plan had as a priority, to modernize research infrastructures and create new ones. This explains why the first plan was sometimes called 'the concrete plan'. At the end of the 1990s, a major change had taken place throughout Japanese society, in the media and the techno-structure: it became clear that this crisis had no bottom and would have no end. It was not a crisis that could be overcome so that Japan would return to its former situation. There would be no return, but rather a transition toward a different society and economy. Anxiety was high but people started to look ahead instead of looking back. Reforms had to be experimented with and not feared, even if nobody knew which would be the right ones. This was the third step, and this spirit continues until today.

The Second Basic Plan, from 2001 to 2006, did not express this new attitude as it was too soon. It had as its goal, to reform in-depth the universities, to draw a line between public and private universities and to give public universities financial and administrative autonomy. Public universities had to become accountable for their management (including profitability) and for their research and teaching performance (Oba 2010; see also Woolgar 2007). This reform should lead to a higher degree of mobility for professors and researchers. To stimulate research and open new fields, a Center of Excellence (COE) program was established to provide financial incentives for competition among innovative academic projects. The effective outcome of such reforms is always below expectation. Nonetheless, the COE program has stimulated innovative interdisciplinary research projects in many fields.

The Third Basic Plan, from 2006 to 2011, was launched in March 2006 (NISTEP 2005). Its conception and goals were different from the two previous plans. It expressed this third step, a new attitude and a collective will to lead the transition to its end. It was based on a large inquiry to identify both the worldwide state of research and the specific needs of the Japanese population. The goal was to respond to the economic and financial situation of the nation and to take into account its social constraints: the aging population, the demographic decline and low birth rate, the ecological transition, the rising cost and growing scarcity of energy, increased competition with the Chinese economy and growing international instability. ${ }^{23}$ At mid-course, the third plan was disrupted by the 2007 systemic crisis. Japan was hit where it hurt the most: its economy was partially restructured and since 2004 and 
2005 it had started to grow. But the year 2008 proved how fragile this growth and recovery were; high-tech industries were far too dependent on foreign markets and on global economic growth. The time of an export-oriented economy based on increasingly higher-value-added industries and products could no longer sustain Japan's long-term economic and social development. Furthermore, industrial nations had one after another implemented the same strategy since the late 1990s. This strategy was understood in Japan as leading to a dead end. The time had come to escape from this trap. The resulting adaptation and revision strongly influenced the conception of the next plan. The third plan was expressing what should be called the social turn of science and technology policy in Japan. This is a fourth step, leading beyond the national system of innovation model.

The Fourth Basic Plan (2011-2015) was supposed to be launched in March 2011, a few days before the Kanto-Tohoku earthquake and the Fukushima catastrophe. It was postponed and then revised. Naoto Kan's government validated the final version of the fourth plan on 19 August 2011. In order to respond to the 2008 crisis, discussions have been far more open and inclusive because the fourth plan has to make a real difference in order to justify the same level of public investment. People will have to see changes in their daily lives, their standard of living and in public services. According to available documents, the plan will intensify the third plan's orientation toward solving pressing problems. Small and medium-size companies, and even new industries, new jobs, new services responding to the present needs of the population are expected to be created or reinforced. The fourth plan is raising high expectations and it is responding to the growing disappointment with science and technology policies by introducing a criterion of 'social accountability'. In summary, innovation has to make sense and sell, to produce growth, create jobs and satisfy real needs. Beneath such marketing and political slogans, a real problem is raised by the present Japanese techno-structure: the present systemic crisis requires a deep revision of the economic strategy based on scientific progress and technological innovation designed since the mid-1990s.

An intense debate has taken place since 2008. A consensus has been reached between the various institutions and interests participating in the conception, financing and implementation of the Fourth Basic Plan. ${ }^{24}$ According to this 'new paradigm of innovation', and in order to 'benefit the Japanese people', specialists in policy design need to learn how to articulate and manage different goals within the same policy. These 
policies have to respond to practical goals and at the same time sustain world-class research. These objectives require innovations in research governance: a different way of conceiving, organizing and managing research and innovation processes has to be implemented. Because no models are available, the only solution is to experiment. No version of the top-down 'linear model ${ }^{125}$ can be expected to work. Discussions and various documents, debates and reports ${ }^{26}$ indicate that the present goal is to identify real social needs and to satisfy these needs by creating new products responding to present demand and values, needs and buying power. In this perspective, the neo-liberal conception of the market is not the centre of a social system: society, people in their daily lives and problems, are considered the centre of society. The problem is not to reform an existing 'national system of innovation' but to reorganize innovation from the point of view of the society. Debates and research show that the goal is to negotiate and organize the emergence of a new 'innovation ecosystem' within society itself. This is a major social and epistemic experiment: to learn how to bring into a constructive debate various actors and partners from very different sectors and with different interests and values. ${ }^{27}$ It is also a major challenge. After such cumulative crises, many Japanese think they have no choice.

Finally, the social turn is a response to the ecological challenge, which will in the coming decades transform all social and economic systems. Before the earthquake, the Council for Science and Technology Policy selected two priority fields: ${ }^{28}$ energy and environment technologies and health and bioscience. This partition reproduces the 1992 distinction between the Industrial Science and Technology Frontier Program and the New Sunshine Program. But today in 2011, 'society' and 'ecosystem of innovation' are the two notions supposed to operate recoupling by articulating these two main research fields on practical social and industrial solutions. The ecological challenge is supposed to integrate research, the economy and society.

The Fourth Basic Plan was considered both a necessity and an experiment: a necessity to respond to the 2008 crisis but also an experiment because the plan had to deliver tangible results by articulating long-term research goals and the realities of present Japan. Its August revision confirms the general orientation of the Fourth Basic Plan. It is focused on reconstruction with the goal of 'revitalizing Japan' through basic research within the 'development of policy creation and promotion with society'. This is easier said than done. By an unpredictable twist of fate, what was considered an experiment became in 11 March 2011 a necessity: relocat- 
ing people and activities and rebuilding the Kanto-Tohoku regions will have ripple effects throughout Japan. This cannot be achieved without evaluating and taking into account the daily needs of the victims and all people affected by the disaster. The social turn of research and innovation policies in Japan introduces a new step in the conception, management and evaluation of research and innovation policies. It develops on two legs. It intends to find solutions to the present systemic crisis from the point of view of society. It responds to the ecological challenge by criticizing and opposing the interests and power of utilities companies. The Fukushima catastrophe has forever transformed the relations between government, nuclear technology, utilities companies and society. The green turn of both Japanese industry and society will intensify. It is a field where Japanese innovation practices will probably thrive, create jobs, investment opportunities and eventually new industries. The crisis and the catastrophe are forcing Japan to be creative and find new solutions. This is a new attitude: the goal is not to compete, it is first to solve problems. Maybe Japanese society needed this impulse to overcome its deconstruction. The social and green turn, their conjunction and interactions are restructuring an innovation system already reformed in the 1990s. But the real challenge, in the present reconstruction phase, is to progress and implement it fast.

\section{Conclusion: Beyond Neo-liberalism}

An intense decoupling process has revolutionized industrial systems since the 1980s. Its source is to be found in the growing ecological constraint on all economies and societies. But this decoupling process has also opened, since the late 1970s, the search for a recoupling process to control and master the internal deconstruction of social and economic systems and increased international competition. Two sets of alternative answers can be observed and compared. Both paradigms have in common reliance on innovation for sustaining growth and competitiveness. But these two solutions compete with each other. The neo-liberal paradigm took shape in the US in the early 1980s. It finds a response by increasing the autonomy of the economic sphere within a social system: research and innovation institutions have been progressively reformed in order to feed the economy. Since the early 2000s, science and technology policies have failed to reshape the US economy. Neo-liberal policies seem to inspire an endless decoupling: no ground for rebound has been found. The research and innovation paradigm was first developed in 
Japan in the mid-1990s. It was expected to find a solution by designing large-scale science and technology policies to create the conditions for endogenous and long-term social and economic growth. Today, the neoliberal paradigm seems to be the cause of the present systemic crisis. In the last ten years, most industrial nations have adopted a version of the research and innovation paradigm.

Japan is often considered a dragon of the last century. But by inventing such a solution to its complex crisis, Japan is in advance and a forerunner, whatever the difficulties and results of its fourth Basic Plan. Reforms have been many and others are coming, but they all have for a goal to reach a recoupling process. It is impossible to predict what Japan's fourth Basic Plan will achieve. But the social turn of Japan's science and technology policy is an experiment to be carefully followed in order to learn from it. It is an alternative to the neo-liberal paradigm and a step beyond the neo-liberal era.

Alain-Marc Rieu is professor of contemporary philosophy and science studies at the University of Lyon and senior researcher at the Institute of East-Asian Study at the Ecole Normale Supérieure de Lyon. Since the 1970s he has been studying the mutation of the role, conception and organization of knowledge in advanced industrial societies. He now concentrates on a comparative study of science and technology policies (http://w7.ens-lyon.fr/amrieu/).

\section{NOTES}

1 The system model used in this paper is mainly derived from the work of H. Maturana and F. Varela on autopoietic processes: a system is what associates a structure to its environment (see Varela, Maturana \& Uribe 1974). The perspective finds its root in the work of Michel Foucault, in his conceptions of 'governmentality' and power. It is also influenced by Niklas Luhmann's work (see Raasch 2001). The idea of decoupling is mainly based on neo-Darwinian and non-Darwinian models of evolution (see Depew \& Weber 1995).

2 A typical example is Anderson (2009).

3 For instance, Anderson (2009).

4 Now (Fall 2011), the crisis is systemic because it is all at once financial, economic, social and monetary. It became political in 2010 when the solution to the 2008 financial crisis led to a sovereign debt crisis, which concerns the basic functions of all nation-states: security, defense, social policies, education.

5 This issue and the crucial role of science policy to bring solutions is fully identified in Freeman \& Soete (1999).

6 In the sense, ecology is defined as an 'associated environment' (milieu associé), a notion derived from Gilbert Simondon (1969). The world is composed of various ecologies connected (or not) to each other.

7 It was the object of President Eisenhower's famous 1961 farewell address on the 
'military-industrial complex'. See also Johnson (2004).

8 Concerning the interaction and competition between national systems of innovation and science and technology policies, see Rieu (2008).

9 For a recent synthesis, see Lundvall (2010); for a retrospective view, see Godin (2009).

10 I do not refer here to the further decoupling within the economic sphere since the 1980s of financial activities from industrial activities. This further decoupling has triggered the present crisis and is the main obstacle to overcoming it.

11 Neo-liberal theory and policies were considered as the source of the globalization process and the last step of European modernity and American hegemony (see Shani 2003). The present systemic crisis has intensified this debate in all East Asian nations.

12 Evaluating the Koizumi legacy is a continuing debate inside and outside Japan.

13 On the presuppositions and various types of neo-liberalism, see Foucault (2004). Half the book contrasts German neo-liberalism with American neo-liberalism.

14 A report for MITI under the direction of Watanabe Chihiro, Industry-ecology: introduction of ecology into industrial policy (English summary), was published in Tokyo in May 1972. It deals with the severe industrial pollution of the post-war reconstruction (cited by Erkman 1997).

15 For a recent synthesis, see Lundvall (2010), note 9.

16 Johnson (1982) studies the formation of the institutional system (the 'developmental state') before and after the Pacific War, which would respond to the energy crisis of the 1970s.

17 Sakaiya Taichi explicitly formulated this paradigm in his book The Knowledge Value Revolution (1991). He became director of the Economic Planning Agency in the late 1990s.

18 Many specialists of Japan reinforced this exaltation (see Abegglen \& Stalk 1985; Prestowitz 1988).

19 Toffler's, The Third Wave (1980) had a major influence in Japan.

20 The Japanese Democratic Party, which came into power in September 2009, started to question and evaluate the goals, funding and reforms of Japan's system of research, training and innovation. The 11 March 2011 catastrophe is reinforcing this critical evaluation. Since Fall 2010, universities have proven they constitute a strong lobby.

21 A Japanese school of technology management was organized under the direction of Watanabe Chihiro, a former MITI executive, at Tokyo Institute of Technology.

22 The Daily Yomiuri (Tokyo), 11 January 1994.

23 Reports and studies are available at the website of National Institute for Science and Technology Policy (NISTEP): www.nistep.go.jp/.

24 I have drawn from articles and presentations by Arimoto Tateo, Director of the Research Institute of Science and Technology for Society (RISTEX), Japan Science and Technology Agency, and from conversations with Mrs. Harayama Yuko, Tohoku University and OECD. See Arimoto (2006).

25 The 'linear model' supposes the transfer from research institutions to firms, which in turn develop new products and services and finally sell them on the market. See Godin (2009), note 9.

26 See the RISTEX website: http:/ / www.ristex.jp/EN/.

27 This situation is similar to experiments in Japan and elsewhere described by Callon, Lascoumes \& Barthe (2009).

28 http://www8.cao.go.jp/cstp/english/policy/reports.html. 


\section{REFERENCES}

Abegglen, James and G. Stalk 1985. Kaisha. The Japanese corporation. New York: Basic Books.

Anderson, Jonathan 2009. 'Decoupling Asia's growth. Emerging markets poised to perform'. Far Eastern Economic Review, (September): 8-12.

Arimoto, Tateo 2006. 'Innovation policy for Japan in a new era', in Recovering from success: innovation and technology management in Japan, edited by $\mathrm{H}$. Whittaker and R. Cole, 237-254. Oxford: Oxford University Press.

Callon, Michel, Pierre Lascoumes and Yannick Barthe 2009. Acting in An Uncertain World: An Essay on Technical Democracy (trans. Graham Burchell). Cambridge: MIT Press.

Depew, David and Bruce Weber (eds.) 1995. Darwinism evolving. System dynamics and the genealogy of natural selection. Cambridge: MIT Press.

Dore, Ronald 2004. 'Japan's new miracle economy: Neo-liberalism and the poverty of wealth'. ZNet, 14 November 2004.

Erkman, Suren 1997. 'Industrial Ecology: An Historical View'. Journal of Cleaner Production, 5(1-2): 1-10.

Foucault, Michel 2004. Naissance de la biopolitique: cours au Collège de France, 1978-1979. Paris: Gallimard-Seuil.

Fransman, Martin 1990. The market and beyond: cooperation and competition in Information Technology development in the Japanese System. Cambridge: Cambridge University Press.

Freeman, Christopher 1987. Technology Policy and Economic Performance: Lessons from Japan. London: Pinter.

Freeman, Christopher 1988. 'Japan: A new national innovation system?', in Technology and economy theory, edited by G. Dosi, C. Freeman, R.R. Nelson, G. Silverberg and L. Soete. London: Pinter.

Freeman, Chris and Luc Soete 1999. 'Technology and the environment', in The economics of industrial innovation, (2nd ed.), edited by Chris Freeman and Luc Soete, 413-423. Cambridge: MIT Press.

Godin, Benoît 2009. 'National innovation system: the system approach in historical perspective'. Science, technology and human values, 34 (4): 476-501.

Ito, Youichi 1991. 'Birth of Joho Shakai and Johoka concepts in Japan and their diffusion outside Japan'. Keio Communication Review, 13: 3-12.

Johnson, Chalmers 1982. MITI and the Japanese Miracle: The Growth of Industrial Policy, 1925-1975. Stanford: Stanford University Press.

Johnson, Chalmers 2004. Blowback. The Costs and Consequences of American Empire, (2nd ed.). New York: Holt Paperbacks.

Kodama, Fumio 1991. Analyzing Japanese High Technologies: The Techno-Paradigm Shift. London: Thomson Learning.

Kodama, Fumio 1995. Emerging patterns of innovation: sources of Japan's technological edge. Cambridge: Harvard University Press.

Lee, Yong Wook 2008. The Japanese challenge to the American neo-liberal world order. Stanford: Stanford University Press.

Lundvall, Bengt-Ake (ed.) 2010. National Systems of Innovation: Toward a Theory of Innovation and Interactive Learning. London: Anthem Press.

National Institute for Science and Technology Policy (NISTEP) 2005. Comprehensive Analysis of Science and Technology Benchmarking and Foresight, Report no. 99. Tokyo: NISTEP.

Oba, Jun 2010. 'L'autonomisation des universités nationales au Japon: l'impact de la réforme de 2004', Ebisu (Tokyo: Maison franco-japonaise), 43 (spring-summer): 83-122. 
Prestowitz, Clyde 1988. Trading places: How America allowed Japan to take the lead. New York: Basic Books.

Raasch, William 2001. Niklas Luhmann's Modernity: The paradoxes of differentiation. Stanford: Stanford University Press.

Rieu, Alain-Marc 1996. 'Japan as a techno-scientific society: The new role of research and development'. National Institute for Research Advancement Review (Tokyo), Autumn: 3-6. Available from: http://www.nira.or.jp/past/publ/review/96autumn/rieu. html.

Rieu, Alain-Marc 2007. 'Le Japon comme société de connaissance: quelles leçons pour la France?', in L'empire de l'intelligence: les politiques de recherche japonaises depuis 1945, edited by J.F. Sabouret, 185-216. Paris, CNRS Editions. Available from: http:/ / halshs. archives-ouvertes.fr/halshs-00360130/fr/.

Rieu, Alain-Marc 2008. 'Géostratégie de la recherche et de l'innovation', Hermès 50: 67-73. Available from: http://halshs.archives-ouvertes.fr/halshs-00360140/fr/.

Sakaiya, Taichi 1991. The Knowledge-Value Revolution, Or, a History of the Future. Tokyo: Kodensha International.

Shani, Giorgio 2003. 'The Liberal Project: Globalization, Modernity and Identity. Ritsumeikan Annual Review of International Studies, (Kyoto), 2: 37-57.

Simondon, Gilbert 1969. Du monde d'existence des objets techniques. Paris: Aubier.

Toffler, Alvin 1980. The third wave. New York: Bantam Books.

Varela, F., H. Maturana and R. Uribe 1974. 'Autopoiesis: the organization of living systems, its characterization and a model'. Biosystems, 5: 187-196.

Vogel, Stephen 2006. 'The Koizumi legacy'. Japan Economic Currents, 62(May-June).

Watanabe, Chihiro 1972. 'Industry-Ecology: Introduction of Ecology into Industrial Policy'. (English summary). Tokyo: MITI.

Woolgar, Lee 2007. 'New institutional policies for university-industry links in Japan'. Research Policy, 36(8): 1261-1274. 